\title{
Impact of bioturbation by Arenicola marina on the fate of particle-bound fluoranthene
}

\author{
Liv K. Kure, Thomas L. Forbes* \\ Department of Marine Ecology and Microbiology, National Environmental Research Institute, PO Box 358, \\ Frederiksborgvej 399, DK-4000 Roskilde, Denmark
}

\begin{abstract}
The fate of particle-bound ${ }^{14} \mathrm{C}$-fluoranthene deposited at the sediment-water interface in microcosms with different densities $\left(0\right.$ to $\left.300 \mathrm{~m}^{-2}\right)$ of Arenicola manna was followed for $28 \mathrm{~d}$. Worms had a pronounced effect on the degradation rate of fluoranthene. Defecated material quickly buried the surface layer of ${ }^{14} \mathrm{C}$-fluoranthene into deeper layers of the sediment, where degradation of fluoranthene was much slower than at the more reactive surface sediment in microcosms without $A$. marina. Only 0.3 and $2.9 \%$ of ${ }^{14} \mathrm{C}$-fluoranthene was mineralised to ${ }^{14} \mathrm{CO}_{2}$ after $28 \mathrm{~d}$ in treatments with and without $A$. marina, respectively. There was no significant difference between degradation rates among different densities of A. marina, although the mixing of fluoranthene into deeper sediment layers was enhanced at higher worm densities. The $\mathrm{DO}^{14} \mathrm{C}$ and $\mathrm{PO}^{14} \mathrm{C}$ (particulate and dissolved organic ${ }^{14} \mathrm{C}$ ) in the overlying water were negatively related with worm density. The ventilating currents of $A$. marina may have repositioned ${ }^{14} \mathrm{C}$-activity from the water into deeper sediment layers, which then acted to filter both dissolved and bound fluoranthene. ${ }^{14} \mathrm{C}$-activity was high in worms after $28 \mathrm{~d}$, approximately an order of magnitude higher than that mineralised to ${ }^{14} \mathrm{CO}_{2}$ during this period. The removal of deposited organic contaminants on sediment surfaces through degradation at the highly reactive sediment-water interface or through local transport by currents or wave action can be reduced as a result of burial of contaminants by bioturbating organisms. Contaminants may thus persist longer in the sediment environment and will be released from the sediment over a prolonged period of time. Enhanced biological transport of contaminants to depth can lead to increased exposure of infauna.
\end{abstract}

KEY WORDS: Bioturbation - Arenicola marina Fluoranthene $\cdot \mathrm{PAH} \cdot$ Degradation $\cdot$ Sediment

\section{INTRODUCTION}

Sediment processing by infauna modifies the physical and chemical nature of sediments. Increased particle and solute transport within the sediment through bioturbation also enhances the microbial degradation of organic material in sediments and the release of nutrients from sediments (e.g. Aller 1980, Hylleberg \& Henriksen 1980, Aller \& Yingst 1985, Kristensen \& Blackburn 1987. Andersen \& Kristensen 1991, Banta et al. 1995). Oxygen is not only a key factor in organic matter degradation processes in sediments (Aller 1994) but also of utmost importance for determining the fate

·E-mail: tf@dmu.dk of contaminants (Bauer \& Capone 1985, Mihelcic \& Luthy 1988). The ventilation of burrows by infauna enhances oxygen flux into deeper layers of the sediment and increases the flux of metabolic inhibitors from the sediment. These important changes in porewater constituents, in conjunction with a bioturbationmediated increased accessibility of organic matter and dissolved nutrients, stimulate microbial activities in the deeper layers of the sediment (Yingst \& Rhoads 1980 , Van Duyl et al. 1992).

Macrofaunal activities in sediments-especially those of deposit-feeding polychaetes-affect the fate of organic pollutants in sediments. Bioturbation by Arenicola marina reduced the oil content in sediment after an oil spill (Gordon et al. 1978), Capitella capitata increased the microbially mediated degradation rate of 
fluoranthene by a factor of 2 (Gardner et al. 1979) and C. capitata also increased the degradation of benzo(a) pyrene in sediments (Lee et al. 1979). Finally Clymenella torquata reduced oil concentrations in the surrounding sediment by up to $50 \%$ in microcosm experiments (Koerting-Walker \& Buck 1989). Sediment-associated contaminants can be removed by uptake into the worms, enhanced microbial degradation, or by resuspension to surface waters.

The fate of organic matter after deposition on the sea floor in the presence and absence of bioturbation has been the subject of several studies (e.g. Andersen \& Kristensen 1992, Kristensen et al. 1992, Andersen 1996). The fate of organic contaminants deposited at the sediment-water interface has received comparatively little attention. Nevertheless, degradation of organic contaminants such as polycyclic aromatic hydrocarbons (PAH) in sediments and soils is presumably dependent on availabilily of oxygen, and subduction of these contaminants into deeper anoxic layers through bioturbation could potentially cause the contaminants to persist much longer in the environment. Most studies report how bioturbation increases degradation rates, but there is reason to believe that bioturbation by head-down deposit feeders may decrease degradation rates.

The deposit-feeding polychaete Arenicola marina was chosen for this study because it is a common species in the coastal zone around Denmark, it moves large quantities of sediment a long distance during feeding, and it can be described as a 'functional keystone organism' in these ecosystems (Grimm 1995, Forbes \& Kure 1997). A. marina has a great impact on ecosystem structure and function because of its ability to change sediment chemistry and physical properties and therefore to a large extent control species composition and abundance (Reise 1983, Brey 1991, Flach 1992, Flach \& Beukema 1994, Beukema 1995).

The feeding behaviour and physiology of Arenicola marina are well studied and were recently reviewed by Zebe \& Schiedek (1996). It is a head-down deposit feeder ingesting sediment at a depth of 10 to $30 \mathrm{~cm}$ and defecating at the surface. As a result of sediment moving downward within a spatially restricted zone, a funnel is often formed at the sediment surface, where newly deposited organic matter can be trapped and subsequently will enrich the sediment ingested at depth. Depending on the nature of the sediment, transport time from sediment surface to feeding pocket and back up to the sediment surface may take only a few hours (Rijken 1979, Grossmann \& Reichardt 1991). In the field, worms often change position of both feeding pocket and tail shaft (Brey 1991, Retraubun et al. 1996). This mode of feeding typically results in a fast and thorough mixing of the upper layer of the sedi- ment. A marina ingests 10 to $20 \mathrm{ml} \mathrm{g}^{-1}$ body wet weight $\mathrm{d}^{-1}$ (Zebe \& Schiedek 1996) and is thus capable of transporting 4 l of sediment through its gut per year (Cadée 1976). Transport of water across the sedimentwater interface (irrigation) by $A$. marina is also important-on the order of 1 to $2.5 \mathrm{l}$ water $\mathrm{d}^{-1}$ is pumped down through the tail shaft and back to the overlying water, presumably through the feeding funnel (Jacobsen 1967, Hüttel 1990). Irrigation by A. marina has a great effect on sediment chemistry (Hüttel 1990) and local meiofaunal species composition (Reise 1983).

Fluoranthene was chosen as a model compound for the hydrophobic organic contaminants in this study because it is one of the most abundant PAHs in the environment (Shiaris \& Jambard-Sweet 1986), and because it is highly hydrophobic with an octanol water partitioning coefficient, $\log K_{\text {ow }}$ of 5.2 (Rav-Acha \& Rebhun 1992) and is thus strongly associated with particulates. Compared to other PAHs of this size, it is relatively resistant to photolytic and microbial degradation in sediments and it bioaccumulates readily (Landrum 1989). Fluoranthene is also one of the most acutely toxic PAHs (Swartz et al. 1990).

The objectives of the present study were to establish the degradation rates of a surface-deposited particlebound hydrophobic organic contaminant in undisturbed and bioturbated sediment and to investigate how bioturbation affected the distribution of the contaminant within the sediment. The effect of bioturbation by Arenicola marina on degradation rate and transport of fluoranthene in sediment was followed for $4 \mathrm{wk}$ in microcosms using ${ }^{14} \mathrm{C}$-labelled fluoranthene. Different levels of bioturbation were achieved by manipulating A. marina density.

\section{MATERIALS AND METHODS}

Microcosms. Microcosms were clear polyacrylic cores $23 \mathrm{~cm}$ high and $11 \mathrm{~cm}$ in diameter. The microcosms were filled with 1.51 wet sandy sediment and $500 \mathrm{ml} \mathrm{GF} / \mathrm{F}$-filtered sea water with a salinity of $14 \%$ collected from Roskilde Fjord (Denmark). The sediment was sieved through a $1 \mathrm{~mm}$ mesh sieve to remove larger particles and macrofauna. An organic carbon content of $0.47 \%$ was measured using a Perkin Elmer CHN-analyser (model $240 \mathrm{C}$ ) after removal of carbonates by acid fuming ( $\mathrm{HCl}$ ). The median particle size of the sediment used was $217 \mu \mathrm{m}$.

Small individuals of Arenicola marina, with an average $( \pm \mathrm{SD})$ wet weight of $0.968 \pm 0.088 \mathrm{~g}$ (not including gut contents), were collected from the same site. Zero, 1, 2 or 3 worms - corresponding to densities of approximately $0,100,200$ and $300 \mathrm{~m}^{-2}$ - were introduced into 3 microcosms each. An additional 2 microcosms with- 
out worms were prepared for sampling at the beginning of the experiment. Sediment and worms were acclimated for $8 \mathrm{~d}$. The temperature was held constant at $18^{\circ} \mathrm{C}$ and salinity at $14 \%$, levels similar to those found at the sampling site. Ambient air, which was filtered to remove particulates and oil, was pumped continuously through the water in the microcosms at a rate of $29 \mathrm{ml} \mathrm{min}^{-1}$ to ensure oxygenated conditions in the water column throughout the experiment. Oxygen content was determined using the Winkler method and was found at all times to be $>90 \%$ of saturation. The microcosms were kept dark to prevent photo-degradation of fluoranthene and ${ }^{14} \mathrm{CO}_{2}$ incorporation into algae.

$14 \mu \mathrm{Ci}$ of fluoranthene- $3{ }^{14} \mathrm{C}$ (SIGMA, specific activity $55 \mathrm{mCi} / \mathrm{mmol}$, purity $>98 \%$ ) dissolved in $14 \mathrm{ml}$ of acetone was added to $280 \mathrm{~g}$ of air-dried sediment. The sediment was mixed well with a spatula and left for $3 \mathrm{~h}$ to let the acetone evaporate. Water was changed in the microcosms and $20 \mathrm{~g}{ }^{14} \mathrm{C}$-fluoranthene-spiked sediment $(\approx 1 \mu \mathrm{Ci}$ ) was sprinkled over the surface of each of the 14 microcosms

Initial samples from the additional 2 microcosms without worms were taken $1 \mathrm{~h}$ after ${ }^{14} \mathrm{C}$-fluoranthene-spiked sediment was added. The remaining 12 microcosms were left for $4 \mathrm{wk}$, during which radioactivity was monitored in air and water as described below.

Air. Out-flowing air passed through $2 \mathrm{CO}_{2}$ traps consisting of $20 \mathrm{ml}$ glass vials with $10 \mathrm{ml}$ of $0.5 \mathrm{M} \mathrm{NaOH}$ connected in a series (Fig. 1). Trap efficiency at a flow rate of $29 \mathrm{ml} \mathrm{min}{ }^{-1}$ was $97 \%$ (tested with ${ }^{14} \mathrm{C}$ $\mathrm{NaHCO}_{3}$ ). Traps were changed on Days 1, 3 and 7. On Days 14 and 28 the rate of ${ }^{14} \mathrm{CO}_{2}$ release was determined from the collection of ${ }^{14} \mathrm{CO}_{2}$ over $24 \mathrm{~h}$. The ${ }^{14} \mathrm{CO}_{2}$ release rates on Days 14 and 28 were also used in the calculation of the cumulative ${ }^{14} \mathrm{CO}_{2}$ loss. Ten ml of Insta Gel (Packard Inc.) was added and the vials

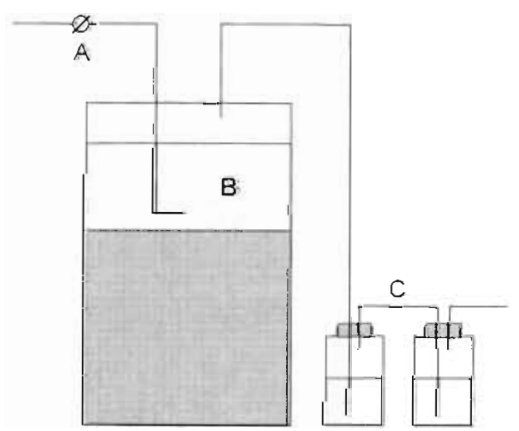

Fig. 1. Experimental set-up. Ambient filtered air (A) pumped into microcosm (B) with sediment, water and air Radiolabelled ${ }^{14} \mathrm{CO}_{2}$ was stripped from the out-flowing air by traps (C) which consisted of 2 vials, each containing $10 \mathrm{ml}$ of $0.5 \mathrm{M} \mathrm{NaOH}$ were counted on a liquid scintillation counter (LSC) (Beckman LS 1801) and corrected for quench.

Water. Overlying water was sampled for ${ }^{14} \mathrm{C}$-activity each time the $\mathrm{CO}_{2}$ traps were changed. Total activity was determined in $10 \mathrm{ml}$ of water taken directly from the microcosms, and the total (dissolved+particulate) organic ${ }^{14} \mathrm{C}$ content $\left(\mathrm{DO}^{14} \mathrm{C}+\mathrm{PO}^{14} \mathrm{C}\right.$ ) was determined in $10 \mathrm{ml}$ of water after acidification with $0.5 \mathrm{ml}$ of $0.5 \mathrm{~N}$ $\mathrm{HCl}$ and degassing with nitrogen. Ten $\mathrm{ml}$ of Insta Gel was added to the water and activity was determined using LSC and quench correction. The difference between total ${ }^{14} \mathrm{C}$ and total organic ${ }^{14} \mathrm{C}$ in water was calculated and added to the ${ }^{14} \mathrm{CO}_{2}$ found in $\mathrm{NaOH}$ traps to give total ${ }^{14} \mathrm{CO}_{2}$ release. After sampling at Day 14, the water was siphoned off and fresh, filtered water was carefully added.

Sediment. Three sub-cores of $2.5 \mathrm{~cm}$ diameter and $15 \mathrm{~cm}$ length were taken from each microcosm. The additional 2 microcosms, representing initial conditions, were sampled after $1 \mathrm{~h}$ and the remaining 12 microcosms were sampled after 4 wk. Cores were sliced into 1 or $2 \mathrm{~cm}$ layers. Porosity was determined in each layer from the water loss after freeze drying, and bulk density (weight of known volume) of the sediment was determined using the equation:

$$
\phi=f_{\mathrm{w}} \cdot m_{\mathrm{sed}} /\left(\rho_{\mathrm{w}} \cdot V_{\text {sed }}\right)
$$

where $\phi$ is the porosity (unitless), $f_{w}$ is the fraction of water in wet sediment (unitless), $m_{\text {sed }}$ is the wet weight of a known volume of sediment $(g), \rho_{w}$ is the density of sea water at $14 \%\left(\mathrm{~g} \mathrm{~cm}^{-3}\right)$, and $V_{\text {sed }}$ is the known volume of wet sediment $\left(\mathrm{cm}^{3}\right)$.

Total activity in freeze-dried sediment samples was determined by adding $1 \mathrm{ml}$ of Solusol (Packard Inc.) to $1 \mathrm{~g}$ of freeze-dried sediment. Samples were left overnight, sonicated for $5 \mathrm{~min}, 9 \mathrm{ml}$ of Ultima Gold (Packard Inc.) was added, and the samples were counted and corrected for quench. The results are given as dpm g ${ }^{-1}$ dry weight.

Arenicola marina. Worms were recovered from the microcosms after sediment sampling. Wet weight was determined for intact individuals after allowing $24 \mathrm{~h}$ for gut evacuation. ${ }^{14} \mathrm{C}$-activity in worms was determined in freeze-dried samples using the same procedure as for sediment.

Statistical analyses. Effect of Arenicola marina density on fluoranthene mineralisation rate, total content of ${ }^{14} \mathrm{C}$-activity in sediment after $28 \mathrm{~d}$, and timeintegrated ${ }^{14} \mathrm{C}$-activity in water were analysed by 1 -way ANOVA. Homogeneity of variances was verified using Bartlett's test prior to ANOVA. Natural logarithmic transformation was applied to homogenise variances in the mineralisation data $(F=1.26, \mathrm{n}=4, \mathrm{p}=$ 0.293 ), all other variances were homogeneous ( $p>0.5$ ) and were not transformed. 


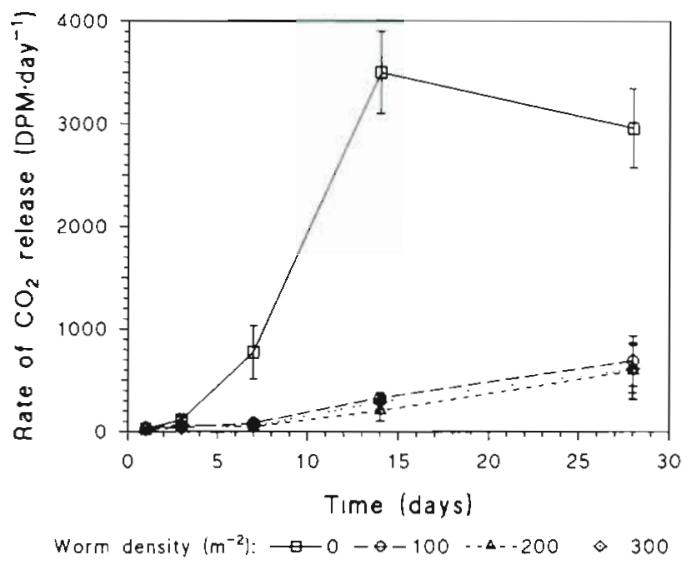

Fig. 2. Rate of ${ }^{14} \mathrm{C}$-fluoranthene mineralisation measured as ${ }^{14} \mathrm{CO}_{2}$ production rate. Mean $( \pm \mathrm{SD})$ values of the 3 microcosms for each worm density are shown

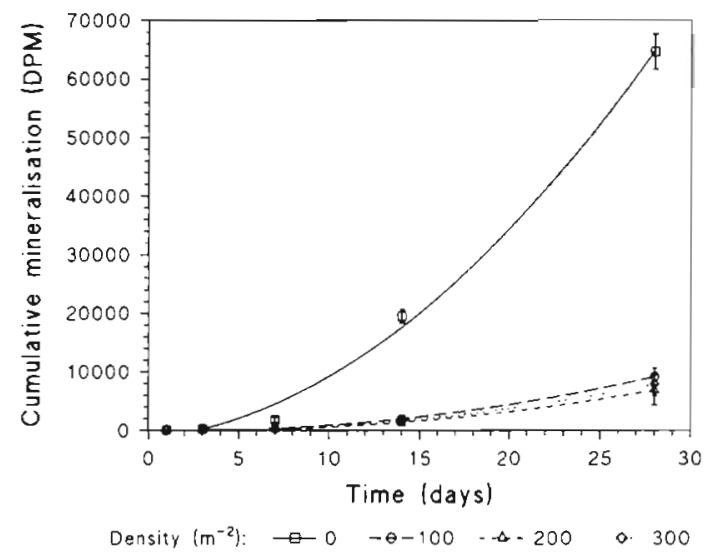

Fig. 3. Cumulative ${ }^{14} \mathrm{CO}_{2}$ production as a function of time. Curves were fitted to ${ }^{14} \mathrm{CO}_{2}(t)=a t^{2}+b t+c_{1} \mathrm{n}=3$ for each density; error bars show $\pm \mathrm{SD}$

Table 1. Degradation of ${ }^{14} \mathrm{C}$-fluoranthene. The best fit to cumulated ${ }^{14} \mathrm{CO}_{2}$ loss with time (see Fig. 3) was ${ }^{14} \mathrm{CO}_{2}(t)=a t^{2}+b t+c$. See text for $t_{00}$ estimations. ( $p<0.0001$ for all curves)

\begin{tabular}{|rrrrcccc|}
\hline Worms m ${ }^{2}$ & $a$ & \multicolumn{1}{c}{$b$} & $c$ & $\mathrm{R}^{2}$ & $t_{0.005}(\mathrm{~d})$ & Mean & $\mathrm{SD}$ \\
\hline 0 & 76.0 & 345.3 & -923.1 & 0.9960 & 10.5 & 11.1 & 0.5 \\
0 & 68.6 & 289.0 & -852.1 & 0.9956 & 11.3 & & \\
0 & 81.2 & 94.1 & -655.8 & 0.9964 & 11.5 & & \\
100 & 11.4 & -44.8 & 35.9 & 0.9998 & 33.2 & 31.0 & 2.7 \\
100 & 10.8 & 4.7 & -42.8 & 0.9984 & 31.8 & & \\
100 & 17.6 & -99.9 & 133.4 & 0.9994 & 28.0 & & \\
200 & 7.4 & -36.5 & 76.2 & 0.9986 & 41.0 & 36.5 & 6.8 \\
200 & 16.5 & -93.2 & 151.0 & 0.9988 & 28.7 & & \\
200 & 8.0 & -41.4 & 58.4 & 0.9994 & 39.9 & & \\
300 & 8.1 & -37.7 & 43.2 & 0.9996 & 39.4 & 33.6 & 5.2 \\
300 & 16.2 & -105.0 & 113.7 & 0.9994 & 29.5 & & \\
300 & 11.7 & -28.0 & 38.7 & 0.9995 & 31.9 & & \\
\hline
\end{tabular}

\section{RESULTS}

\section{Visual observations}

Arenicola marina actively reworked sediment throughout the experiment. Worms and tubes could occasionally be observed at the sides of the microcosms-showing feeding activity at depths of 8 to $12 \mathrm{~cm}$. Fresh faecal material was observed from most individuals daily. The overlying water was changed once (after 2 wk) during the experiment, and this clearly increased worm activity for a short period of time. All worms survived to the 28th day; however, some worms were damaged during sub-coring and could not be used for further analysis. In microcosms without worms a thin ( $1 \mathrm{~mm}$ ) layer of light-brown oxidised sediment was observed at the surface. The rest of the sediment in these microcosms was dark grey and presumably anoxic. In microcosms with $A$. marina only smaller patches of dark sediment were observed. These were most abundant near the bottom. In microcosms with 200 and 300 worms $\mathrm{m}^{-2}$ the layer of ${ }^{14} \mathrm{C}$ fluoranthene at the surface of the microcosms was totally buried by defecated material within a week. At a density of 100 worms $\mathrm{m}^{-2}$ the surface layer was buried within approximately $2 \mathrm{wk}$.

\section{Degradation}

The mineralisation of fluoranthene measured as ${ }^{14} \mathrm{CO}_{2}$ production was much faster in microcosms without worms compared to microcosms with worms, and the rate of ${ }^{14} \mathrm{CO}_{2}$ release increased with time (Fig. 2) Non-linear curve fitting was performed on the cumulative ${ }^{14} \mathrm{CO}_{2}$ data from each microcosm (Fig. 3). Mineralisation of ${ }^{14} \mathrm{C}$-fluoranthene did not follow first order kinetics. Thus mineralisation of fluoranthene was not directly proportional to the actual concentration of fluoranthene. The best fit (highest $\mathrm{R}^{2}$ ) to all data was the quadratic equation

$$
{ }^{14} \mathrm{CO}_{2}(t)=a t^{2}+b t+c
$$

where ${ }^{14} \mathrm{CO}_{2}(t)$ is the cumulative ${ }^{14} \mathrm{CO}_{2}$ production at time $t$ (see Table 1 for details). Mineralisation of ${ }^{14} \mathrm{C}$-fluoranthene to ${ }^{14} \mathrm{CO}_{2}$ was very slow and only 0.3 to $3 \%$ was found mineralised during the experiment. The half life of fluoranthene, which is defined as the time required to mineralise $50 \%$ of ${ }^{14} \mathrm{C}$-fluoranthene to ${ }^{14} \mathrm{CO}_{2}$, thus lies far beyond the time range of this study, and, although it could be calculated from the relationship 


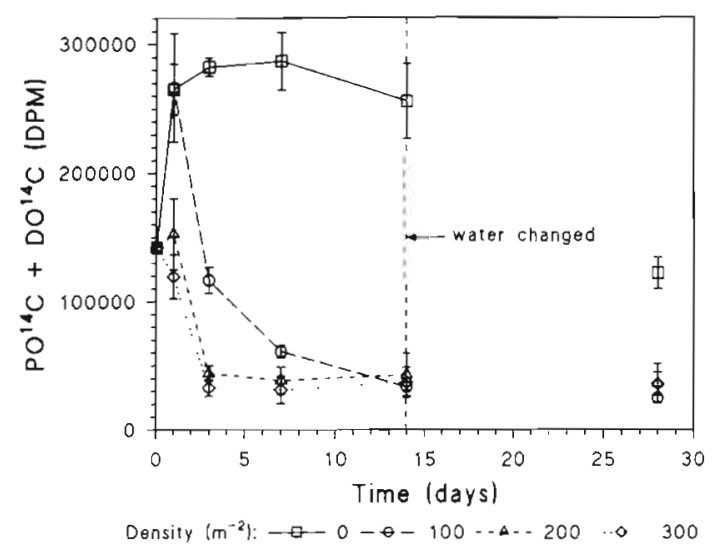

Fig. $4 .{ }^{14} \mathrm{C}$-activity in the overlying water $\left(\mathrm{DO}^{14} \mathrm{C}+\mathrm{PO}^{14} \mathrm{C}\right)$ vs time for the 4 different densities of Arenicola marina. $n=3$ for each density; error bars show \pm SD

found above, such extrapolations may be inaccurate. The time required for $0.5 \%$ of the added ${ }^{14} \mathrm{C}$-fluoranthene to mineralise to ${ }^{14} \mathrm{CO}_{2}\left(t_{0.005}\right)$ was found as the root of Eq. (2) when ${ }^{14} \mathrm{CO}_{2}(t)$ was set to $0.5 \%$ of the initially added ${ }^{14} \mathrm{C}$-activity $(0.005 \mathrm{~A})$ :

$$
t_{0.005}=\frac{-b \pm \sqrt{b^{2}-4 a(c-0.005 A)}}{2 a}
$$

$t_{0.005}$ increased significantly from $11.1( \pm 0.5) \mathrm{d}$ in defaunated sediment to $33.6( \pm 5.1)$ d with Arenicola marina present (mean of all microcosms with $A$. marina) (ANOVA: $F=4.1, \mathrm{n}=12, \mathrm{p}=0.0005$ ). There were no significant differences among $t_{0,005}$ at different densities of A. marina (ANOVA: $F=5.1, \mathrm{n}=9, \mathrm{p}=0.5$ ).

\section{Water}

The organic ${ }^{14} \mathrm{C}$ content $\left(\mathrm{DO}^{14} \mathrm{C}+\mathrm{PO}^{14} \mathrm{C}\right.$ ) increased in water during the first day in all microcosms except those with the highest Arenicola marina density, but decreased thereafter in all microcosms with $A$. marina present (Fig. 4). ${ }^{14} \mathrm{C}$-activity in water in microcosms without worms differed significantly from microcosms with worms (tested on difference in area under the curve in Fig. 4 (ANOVA. $F=276, n=12, p<$ 0.0001 ), and ${ }^{14} \mathrm{C}$-activity in water in microcosms with 100 worms $\mathrm{m}^{-2}$ differed significantly with time from microcosms with 200 and 300 worms $\mathrm{m}^{-2}$ (ANOVA: $F=$ 19.1, $\mathrm{n}=9, \mathrm{p}=0.002$ ). There was no significant difference between the highest 2 densities (ANOVA: $F=$ $1.42, \mathrm{n}=6, \mathrm{p}=0.3$ ).

\section{Sediment}

There was an exponential decrease in ${ }^{14} \mathrm{C}$-activity with depth in the sediment in microcosms without Arenicola marina (Fig. 5A). ${ }^{14} \mathrm{C}$-activity in the surface layer after $28 \mathrm{~d}$ was less than half of the initial ${ }^{14} \mathrm{C}$ -
Fig. 5. Vertical profiles of ${ }^{14} \mathrm{C}$ activity in dry sediment after a surface layer of ${ }^{14} \mathrm{C}$-fluoranthene was added. Mean $( \pm S E$ ) of all subcores sampled from microcosms of identical Arenicola marina densities $(\mathrm{n}=9)$ are shown. (A) Dashed line: microcosms without worms after $1 \mathrm{~h}$; solid line: for each density control microcosms without worms at Day 28 ,

$$
\begin{aligned}
& x=58727 \cdot \exp (-2.98 \cdot C) \\
& r^{2}=0.9737 \\
& x=9323 \cdot \exp (-1.06 \cdot C) \\
& r^{2}=0.9098
\end{aligned}
$$

and

for control sediment at time $1 \mathrm{~h}$ and $28 \mathrm{~d}$ respectively, where $x$ is depth and $C$ is DPM $g^{-1}$ dry weight sediment. ( $B, C$, and D) microcosms with worm densities of 100,200 , and $300 \mathrm{~m}^{-2}$, respectively, at Day 28
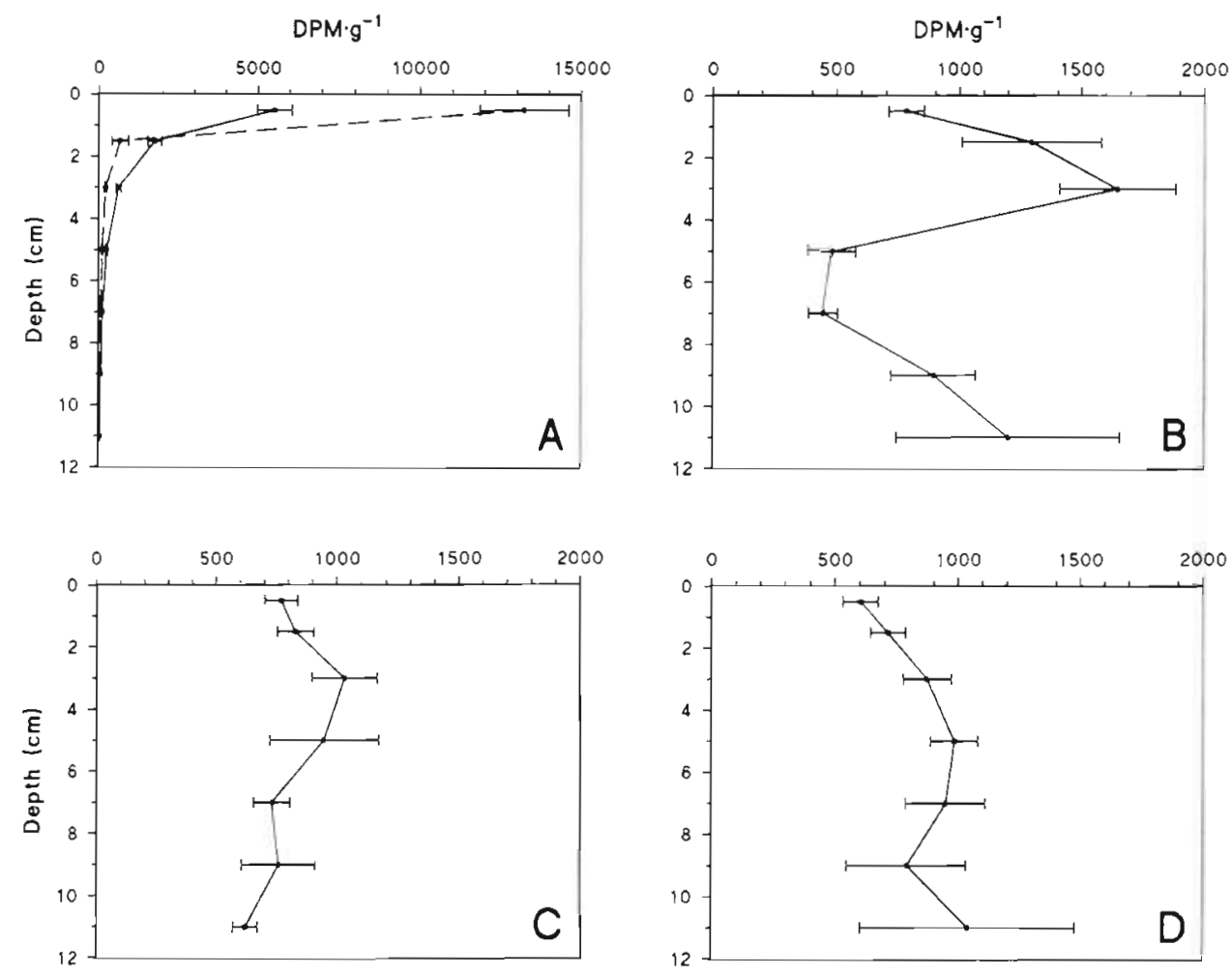


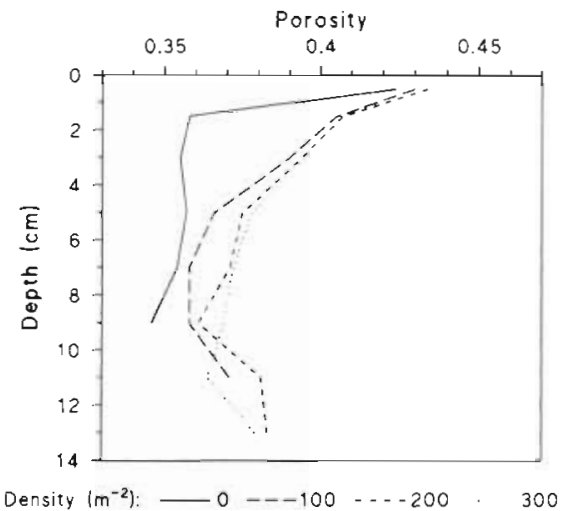

Fig. 6. Mean vertical profiles of sediment porosity at different densities of Arenicola marina after $36 \mathrm{~d} . \mathrm{n}=9$ subcores for each density

activity at Day 0 (5510 compared to $13226 \mathrm{DPM} \mathrm{g}^{-1}$ dry weight). In microcosms with 100 worms $\mathrm{m}^{-2}, 2$ layers were found with relatively high activities. One occurred at or below the feeding depth at 10 to $12 \mathrm{~cm}$ and one at 2 to $4 \mathrm{~cm}$, and this picture was remarkably consistent in all 3 microcosms (Fig. 5B). The upper peak indicated the amount of sediment defecated by the worms at the surface subducting the layer of radiolabelled sediment added at the beginning of the experiment. This burial corresponds to a feeding rate of approximately $7 \mathrm{ml} \mathrm{d}^{-1}$ worm ${ }^{-1}$. At the 2 highest densities of worms the added ${ }^{14} \mathrm{C}$-fluoranthene was mixed homogeneously into the sediment by the worms after 4 wk (Fig. 5C, D).

Sediment porosity increased with increasing density of Arenicola marina (Fig. 6). The total water content in sediment was significantly smaller in microcosms with-

Table 2. Arenicola marina bioaccumulation data. Values are means $( \pm S D)$. BAF is the ratio between tissue and sediment ${ }^{14} \mathrm{C}$-activity on a dry weight basis (an average sediment concentration of $888 \mathrm{DPM} \mathrm{g}^{-1}$ dry weight was used), AF is BAF normalised to worm lipid [10\% of ash-free dry weight (from Taghon et al. 1994)], and sediment organic carbon. Difference in ${ }^{14} \mathrm{C}$ content or AF between densities was not significant at the $95 \%$ level

\begin{tabular}{|lcc|}
\hline & $200 \mathrm{~m}^{-2}$ & $300 \mathrm{~m}^{-2}$ \\
\hline Number of A. marina recovered & 3 & 4 \\
${ }^{14} \mathrm{C}$ concentration, & 456.8 & 353.6 \\
DPM g ${ }^{-1}$ ash free dry weight & $(63.1)$ & $(69.2)$ \\
Individual ${ }^{14} \mathrm{C}$ content & 1.88 & 1.42 \\
as percent total added ${ }^{14} \mathrm{C}$ & $(0.39)$ & $(0.35)$ \\
Accumulation factor, BAF & 514 & 398 \\
& $(71)$ & $(78)$ \\
Accumulation factor, AF & 28.7 & 22.2 \\
& $(4.0)$ & $(4.3)$ \\
\hline
\end{tabular}

out worms than in all microcosms with worms (ANOVA: $F=11.34, n=12, p=0.003$ ) There were no significant difterences among microcosms with worms (ANOVA: $F=2.78, \mathrm{n}=9, \mathrm{p}=0.14$ )

\section{Arenicola marina bioaccumulation}

Unfortunately several worms were damaged during sub-coring in the microcosms and could not be used in the determination of uptake of ${ }^{14} \mathrm{C}$ in worms. Data shown in Table 2 represent only intact worms. Note that Arenicola marina accumulated about 10 times more ${ }^{14} \mathrm{C}$-activity than was found to be mineralised to ${ }^{14} \mathrm{CO}_{2}$ in the microcosms.

\section{Recovery of ${ }^{14} \mathrm{C}$}

About 85.6 to $93.5 \%$ of the activity initially added could be accounted for after 4 wk of the experiment (Table 3$)$. From $63.8( \pm 8.0)$ to $85.9( \pm 6.8) \%$ of the added ${ }^{14} \mathrm{C}$-fluoranthene-activity was found in the sediment. Estimates of the total sediment ${ }^{14} \mathrm{C}$-activity were based on 3 subcores from each microcosm. There was nonhomogeneous distribution, both vertically and horizontally, within microcosms because of Arenicola marina bioturbation; this could lead to inaccurate estimation of levels in the whole sediment. Microcosms with $A$. marina had a significantly higher ${ }^{14} \mathrm{C}$ content in the sediment than did microcosms without worms (ANOVA: $F=4.41, \mathrm{n}=12, \mathrm{p}=0.04$ ). The disappearance of ${ }^{14} \mathrm{C}$ from sediment led to mean loss during the $28 \mathrm{~d}$ of $17.1( \pm 8.5)$ and $36.2( \pm 8.0) \%$ with and without $A$. marina, respectively. In comparison, the mineralisation during the $28 \mathrm{~d}$ measured as evolved ${ }^{14} \mathrm{CO}_{2}$ was 0.3 $( \pm 0.1)$ and $2.9( \pm 0.3) \%$ with and without $A$. marina, respectively.

Table 3. Mean $( \pm \mathrm{SD})$ distribution of ${ }^{14} \mathrm{C}$-activity in the microcosms after $28 \mathrm{~d}$ ( $\mathrm{n}=3$ for each density). Values are given as percent ${ }^{14} \mathrm{C}$-fluoranthene activity initially added to the microcosms. ${ }^{14} \mathrm{C}$-activity in overlying water is the sum of activity in the water removed when the water was changed at Day 14 , the water removed during sampling throughout the experiment, and activity present at Day 28)

\begin{tabular}{|lrrrr|}
\hline & \multicolumn{5}{c}{ Worms $^{-2}$} \\
\cline { 2 - 5 } & 0 & 100 & 200 & 300 \\
\hline Sediment & $63.8(8.0)$ & $85.9(6.8)$ & $77.7(6.5)$ & $85.2(11.6)$ \\
$\mathrm{CO}_{2}$ & $2.9(0.3)$ & $0.4(0.1)$ & $0.3(0.1)$ & $0.3(0.1)$ \\
A. marina & & & $3.8(0.8)$ & $4.3(0.9)$ \\
$\begin{array}{l}\text { Overlying } \\
\text { water }\end{array}$ & $19.0(1.7)$ & $3.6(0.4)$ & $4.1(1.5)$ & $3.7(1.0)$ \\
Total & $85.6(6.4)$ & $88.9(6.4)$ & $85.9(8.0)$ & $93.5(12.0)$ \\
\hline
\end{tabular}




\section{DISCUSSION}

\section{Degradation of fluoranthene}

Feeding by Arenicola marina immediately caused a burial of radiolabelled fluoranthene which then resulted in diminished degradation. Although the mixing rates at the higher densities of $A$. marina (200 and $300 \mathrm{~m}^{-2}$ ) were faster, as indicated by the sediment ${ }^{14} \mathrm{C}$ profiles (Fig. 5), and feeding and irrigation activities by A. marina influenced sediment porosity (Fig. 6), the effect of different levels of bioturbation on mineralisation rates of the subducted ${ }^{14} \mathrm{C}$-fluoranthene was not significantly different between different densities of worms. Bioturbation often has a stimulatory effect on microbial degradation of organic matter in sediments, but this does not necessarily mean that degradation of aromatic compounds such as fluoranthene will also be enhanced. The initial cleavage of a ring structure of PAH requires molecular oxygen (Bauer \& Capone 1985, Hopner et al. 1989). Although the redox potential is greater in bioturbated sediments, free oxygen is still relatively unavailable in deeper layers. Thus higher degradation rates of $\mathrm{PAH}$ are predicted at the sediment surface compared to depth and have been observed by Gardner et al. (1979) and Lee et al. (1979).

The mineralisation rate of fluoranthene in bioturbated sediment observed in the present study increased with time (Fig. 2). Through Arenicola marina feeding activities, ${ }^{14} \mathrm{C}$-labelled sediment that had previously been mixed into deeper layers of the sediment was returned to the surface where degradation was probably faster than at depth. The continuous deposition of ${ }^{14} \mathrm{C}$-labelled compounds at the surface from deeper layers may have contributed to the enhanced degradation with time. The microbial community capable of degrading fluoranthene may have taken longer to adapt when fluoranthene was being mixed into the whole sediment and was present in lower concentrations. A threshold concentration of contaminant below which no adaptation took place was found by Spain et al. (1980). Finally, pre-exposure of the microbial community to organic contaminants (of all kinds) enhances microbial mineralisation of PAHs (Herbes \& Schwall 1978, Heitkamp \& Cerniglia 1987, Heitkamp et al. 1987, Bauer \& Capone 1988). The relatively higher concentration of fluoranthene at the sedimentwater interface may thus have favoured microbial populations capable of degrading fluoranthene compared to populations in the mixed sediment.

The mineralisation of fresh organic matter (e.g. algae) deposited on surfaces of sediment with and without bioturbation typically follows first order kinetics, and rate constants are in the range of 0.02 to $0.07 \mathrm{~d}^{-1}$ for labile pools and 0.002 to $0.008 \mathrm{~d}^{-1}$ for refractory pools (Henrichs \& Doyle 1986, Andersen \& Kristensen 1992). The highest rates of ${ }^{14} \mathrm{C}$-fluoranthene mineralisation observed in this study were 0.03 to $0.1 \% \mathrm{~d}^{-1}$ (at Day 28 ) with and without bioturbation by Arenicola marina respectively. These rates are 2 to 10 times lower than found for refractory organic matter in microcosm experiments.

After $28 \mathrm{~d}$, the oxygenated sediment surface layer in microcosms without Arenicola marina showed metabolisation of fluoranthene at a rate about 5 to 10 times higher than the bioturbated sediment (Fig. 2) because the concentration of ${ }^{14} \mathrm{C}$-fluoranthene in the sediment surface layer (Fig. 5) as well as the content of organic ${ }^{14} \mathrm{C}\left(\mathrm{DO}^{14} \mathrm{C}+\mathrm{PO}^{14} \mathrm{C}\right)$ in the overlying water (Fig. 4) also was about 5 to 10 times higher in microcosms without $A$. marina.

Mineralisation of PAHs in sediments has previously been studied in sediment slurries, where accessibility of nutrients and oxygen to microbes is favoured compared to microcosms or field studies. Even under these conditions degradation of PAHs was relatively slow, with mineralisation rates of 1 to $4 \% \mathrm{~d}^{-1}$ for naphthalene and anthracene (Bauer \& Capone 1985). Heitkamp \& Cerniglia (1987) investigated the mineralisation of different PAHs in microcosms mixed twice a week and found similar mineralisation rates for naphthalene but much slower rates for the larger PAH such as pyrene (approximately 0.1 to $0.2 \% \mathrm{~d}^{-1}$ ). Although experimental conditions vary among different investigations, the mineralisation rate of ${ }^{14} \mathrm{C}$-fluoranthene at the sediment-water interface in undisturbed sediment in this study was comparable to previously found mineralisation rates.

Note that mineralisation of ${ }^{14} \mathrm{C}$-fluoranthene to ${ }^{14} \mathrm{CO}_{2}$ is not equal to the degradation of ${ }^{14} \mathrm{C}$-fluoranthene, since degradation only involves the transformation of the compound, which may not lead to the release of ${ }^{14} \mathrm{CO}_{2}$. The mineralisation rates found in the present study are thus an underestimation of the actual degradation of fluoranthene. The final ${ }^{14} \mathrm{C}$-activity in the sediment was 64 to $86 \%$ of initial values, corresponding to a loss of 14 to $36 \%$ of initially added ${ }^{14} \mathrm{C}$ fluoranthene or 0.5 to $1.3 \% \mathrm{~d}^{-1}$ with and without $A$. marina, respectively. This is an order of magnitude higher than the measured mineralisation rates.

More ${ }^{14} \mathrm{C}$-fluoranthene was lost from sediment not bioturbated by $A$. marina, which is in contrast to the results of Gardner et al. (1979), who found removal rates for fluoranthene in the range of 0.3 to $0.5 \% \mathrm{~d}^{-1}$ without and with Capitella capitata, respectively. Bauer et al. (1988) also found enhanced mineralisation rates of anthracene in sediment with $C$. capitata present. By increasing oxygen content and microbial activity within the sediment, macrofauna can affect mineralisation rates of PAHs in sediments. In the pre- 
sent study, however, the net effect of bioturbation buried and mixed the contaminant into deeper layers of the sediment, where degradation rates were much slower than at the sediment-water interface.

Burial of surface-deposited contaminants through bioturbation has great implications for sediment-living organisms. Because degradation rate and resuspension of particle-bound contaminants to the water column through wave-action and currents are reduced, contaminants will remain in sediments much longer. Exposure to infauna will thus continue for a prolonged period of time.

\section{Water}

Irrigation by Arenicola marina may have been responsible for the removal of ${ }^{14} \mathrm{C}$-compounds from the water phase into either sediment or worm tissue, since the ${ }^{14} \mathrm{C}$-activity lost from water (Fig. 4) was not detected in the $\mathrm{CO}_{2}$ traps (Fig 3), and the removal from the overlying water was related to the density of worms. Particulate-bound or dissolved hydrophobic constituents transported down into the sediment through worm irrigation activity may be trapped in deeper layers of the sediment which may serve as a 'filter' for these compounds. Compounds trapped in the feeding pocket could potentially be available for ingestion and uptake by the worms. Similarly, irrigation by lugworms transports nutrients and oxygen into the worm burrow, and this was hypothesised to stimulate microbial growth and food availability at the feeding pocket (Hylleberg 1975). Krüger (1957, 1971) demonstrated that particulates in the overlying water were removed during passage through sediment when transported by A. marina ventilating currents. Redistribution of a hydrophobic contaminant (Kepone) in overlying water into deeper layers of sediment by the lugworm A. cristata was observed by O'Neill et al. (1985). Although particle mixing is far more important in the transport of hydrophobic contaminants, irrigation by A. marina may contribute to the repositioning of fluoranthene in sediment.

\section{Arenicola marina}

A substantial fraction of the water-associated and particle-bound ${ }^{14} \mathrm{C}$-activity was available for uptake in the worms, as indicated by the high bioaccumulation factors, BAF (Table 2). Bioaccumulation factors normalised to worm lipid and sediment organic carbon (AF) were in the range of 22.2 to 28.7 . This is about 15 times higher than predicted by the equilibrium partitioning model (1.7) (Bierman 1990, Lee 1992) and experimental observations (0.4-1.5) (Driscoll \& McElroy 1996). This exposure model assumes equilibrium between contaminant concentration in the sediment, pore water, and organisms. However, this equilibrium. might never occur in bioturbated sediments. Furthermore, an organism like Arenicola marina might also be exposed to contaminants through ingestion of sediment and assimilation of contaminants in the gut. This exposure route cannot be neglected. It is also possible that $A$. marina ingested surface sediment with high ${ }^{14} \mathrm{C}$-activity that was transported down through the feeding funnel. However, similarly high bioaccumulation factors were observed in A. marina exposed to sediment in which fluoranthene was homogeneously mixed (Kure \& Forbes unpubl.), suggesting that $A$. marina, because it usually feeds on sediment with low organic content, may be especially efficient in assimilation of not only organic matter but also organic contaminants associated with particles.

The role of worm tissue as a 'sink' and place for degradation of organic contaminants is also important. The concentration of ${ }^{14} \mathrm{C}$-activity in Arenicola marina after 28 d was 10 -fold higher than total mineralisation during this period, and the ${ }^{14} \mathrm{C}$-activity found in worms corresponded to 17 to $29 \%$ of the ${ }^{14} \mathrm{C}$-activity lost from the sediment. An additional amount of activity may have been taken up and eliminated or degraded by A. marina during the $28 \mathrm{~d}$, although the capability of degrading PAHs has not yet been demonstrated in $A$. marina. Some polychaetes do possess PAH-degrading enzyme systems or have been found to metabolise PAHs, for example Capitella spp. (Lee et al. 1979, Forbes et al. 1996) and Nereis virens (McElroy 1990).

\section{Conclusions}

Arenicola marina quickly buried the layer of ${ }^{14} \mathrm{C}$-fluoranthene deposited at the surface of the sediment, which decreased the degradation rate of fluoranthene in the sediment. The burial of surface-deposited contaminants through bioturbation may prolong the residence time of particle-bound contaminants in sediments. Such trapped contaminants will be released to the interstitial and overlying water over a prolonged period of time. Consequently, the immediate toxicity to surface-dwelling organisms will quickly be diminished, due to dilution through the burrowing and mixing by bioturbating organisms, but exposure of all organisms to the buried contaminant will be enhanced.

Acknowledgements. We thank Gary Banta and Poul Bjerregaard for critıcal reviews of the manuscript. Financial support was provided by the Danish Research Academy 


\section{LITERATURE CITED}

Aller RC (1980) Relatonships of tube-dwelling benthos with sediment and overlying water chemistry. In: Tenore KR, Coull BC (eds) Marine benthic dynamics. University of South Carolina Press, Columbia, p 285-308

Aller RC (1994) Bioturbation and remineralization of sedimentary organic matter: effects of redox oscillation. Chem Geol 114:331-345

Aller RC, Yingst JY (1985) Effects of the marine deposit-feeders Heteromastus filiformis (Polychaeta), Macoma balthica (Bivalvia) and Tellina texana (Bivalvia) on averaged sedimentary solute transport, reaction rates and microbial distributions. J Mar Res 43:615-645

Andersen $F \varnothing$ (1996) Fate of organic carbon added as diatom cells to oxic and anoxic marine sediment microcosms. Mar Ecol Prog Ser 134:225-233

Andersen $F \varnothing$, Kristensen E (1991) Effects of burrowing macrofauna on organic matter decomposition in coastal marine sediments. In: Meadows PS, Meadows A (eds) The environmental impact of burrowing animals and animal burrows. Proc Symp Zool Soc London, 3-4 May 1990. Clarendon Press, Oxford, p 69-88

Andersen Fø, Kristensen E (1992) The importance of benthic macrofauna in decomposition of microalgae in a coastal marine sediment. Limnol Oceanogr 37:1392-1403

Banta GT, Giblin AE, Hobbie JE, Tucker J (1995) Benthic respiration and nitrogen release in Buzzards Bay, Massachusetts. J Mar Res 53:107-135

Bauer JE, Capone DG (1985) Degradation and mineralization of the polycyclic aromatic hydrocarbons anthracene and naphthalene in intertidal marine sediments. Appl Environ Microbiol 50:81-90

Bauer JE, Capone DG (1988) Effects of co-occurring aromatic hydrocarbons on degradation of individual polycyclic aromatic hydrocarbons in marine sediment slurries. Appl Environ Microbiol 54:1649-1655

Bauer JE, Kerr RP, Bautista MF, Decker CJ, Capone DG (1988) Stimulation of microbial activities in marine sediments inhabited by Capitella capitata. Mar Environ Res $25: 63-84$

Beukema JJ (1995) Long-term effects of mechanical harvesting of lugworms Arenicola marina on the zoobenthic community of a tidal flat in the Wadden Sea. Neth $J$ Sea Res 33:219-227

Bierman VJ Jr (1990) Equilibrium partitioning and biomagnification of organic chemicals in benthic animals. Environ Scj Technol 24:1407-1412

Brey $T$ (1991) The relative significance of biological and physical disturbance: an example from intertidal and subtidal sandy bottom communities. Estuar Coast Shelf Sci 33: $339-360$

Cadée GC (1976) Sediment reworking by Arenicola marina on tidal flats in the Dutch Wadden Sea. Neth J Sea Res 1 $1-2$

Driscoll SK, McElroy AE (1996) Bioaccumulation and metabolism of benzo(a)pyrene in three species of polychaete worms. Environ Toxicol Chem 15:1404-1410

Flach EC (1992) Disturbance of benthic infauna by sedimentreworking activities of the lugworm Arenicola marina Neth J Sea Res 30:81-86

Flach EC, Beukema JJ (1994) Density-governing mechanisms in populations of the lugworm Arenicola marina on tidal flats. Mar Ecol Prog Ser 115:139-149

Forbes TL, Kure LK (1997) Linking structure and function in marine sedimentary and terrestrial soil ecosystems: implications for extrapolation from the laboratory to the field.
In: Van Straalen NM, Lokke H (eds) Ecological assessment of contaminants in soil. Chapman \& Hall, London, p $127-156$

Forbes VE, Forbes TL, Holmer M (1996) Inducible metabolism of fluoranthene by the opportunistic polychaete Capitella sp. I. Mar Ecol Prog Ser 132:63-70

Gardner WS, Lee RF, Tenore KR, Smith LW (1979) Degradation of selected polycyclic aromatic hydrocarbons in coastal sediments: importance of microbes and polychaete worms. Water Air Soil Pollut 11:339-347

Gordon DC Jr, Dale J, Keizer PD (1978) Importance of sediment working by the deposit-feeding polychaete Arenicola manna on the weathering rate of sediment-bound oil. J Fish Res Bd Can 35:591-603

Grimm NB (1995) Why link species and ecosystems? A perspective from ecosystem ecology. In: Jones CG, Lawton JH (eds) Linking species \& ecosystems. Chapman \& Hall, New York, p 5-15

Grossmann S, Reichardt W (1991) Impact of Arenicola marina on bacteria in intertidal sediments. Mar Ecol Prog Ser 77. $85-93$

Heitkamp MA, Cerniglia CE (1987) Effects of chemical structure and exposure on the microbial degradation of polycyclic aromatic hydrocarbons in freshwater and estuarine ecosystems. Environ Toxicol Chem 6:535-546

Heitkamp MA, Freeman JP, Cerniglia CE (1987) Naphthalene biodegradation in environmental micracosms: estimates of degradation rates and characterization of metabolites. Appl Environ Microbiol 53:129-136

Henrıchs SM, Doyle AP (1986) Decomposition of ${ }^{14} \mathrm{C}$-labeled organic substances in marine sediments. Limnol Oceanogr $31: 765-778$

Herbes SE, Schwall LR (1978) Microbial transformation of polycyclic aromatic hydrocarbons in pristine and petroleum-contaminated sediments. Appl Environ Microbiol 35:306-316

Höpner $T$, Harder $H$, Kiesewetter $K$, Dalyan U, KutscheSchmietenknop I, Teigelkamp B (1989) Biochemical aspects of hydrocarbon biodegradation in sediments and soils. In: Gerstl Z, Chen Y, Mingelgrin U, Yaron B (eds) Toxic organic chemicals in porous media. Ecological Studies 73. Springer Verlag, Berlin, p 251-271

Huttel M (1990) Influence of the lugworm Arenicola marina on porewater nutrient profiles of sand flat sediments. Mar Ecol Prog Ser 62:241-248

Hylleberg J (1975) Selective feeding by Aberenicola pacifica with notes on Aberenicola vagabonda and concepts of gardening in lugworms. Ophelia 14:113-137

Hylleberg J. Henriksen K (1980) The central role of bioturbation in sediment mineralization and element re-cycling. Ophelia 1:1-16

Jacobsen VH (1967) The feeding of the lugworm Arenicola manna (L.). Quantitative studies. Ophelia 4:91-109

Koerting-Walker C, Buck JD (1989) The effect of bacteria and bioturbation by Clymenella torquata on oil removal from sediment. Water Air Soil Pollut 43:413-424

Kristensen E, Andersen F $\varnothing$, Blackburn TH (1992) Effects of benthic macrofauna and temperature on degradation of macroalgal detritus: the fate of organic carbon. Limnol Oceanogr 37:1404-1419

Kristensen E, Blackburn TH (1987) The fate of organic carbon and nitrogen in experimental marine sediment systems: influence of bioturbation and anoxia. J Mar Res 45: 231-257

Krüger F (1957) Der Wohnbau von Arenicola als Filtereinrichtung. Naturwissenschaften 44:597

Krüger F (1971) Bau und Leben des Wattwurms Arenicola 
marina. Helgol Wiss Meeresunters 22:149-222

Landrum PF (1989) Bioavailability and toxicokinetics of polycyclic aromatic hydrocarbons sorbed to seduments for the amphipod Pontoporeia hoyi. Environ Scl Technol 23: $588-595$

Lee H II (1992) Models, muddles, and mud: predicting bioaccumulation of sediment-associated pollutants. In: Burton GA Jr (ed) Sediment toxicity assessment. Lewis Publ, Boca Raton, FL, p $267-293$

Lee RF, Singer SC, Tenore KR, Gardner WS, Philpot RM (1979) Detoxification system in polychaete worms: importance in the degradation of sediment hydrocarbons. In Vernberg W, Calabrese A, Thurberg FP, Vernberg J (eds) Marine pollution; functional responses. Academic Press, New York, p 23-37

McElroy AE (1990) Polycyclic aromatic hydrocarbon metabolism in the polychaete Nereis virens. Aquat Toxicol 18 : 35-50

Mihelcic JR, Luthy RG (1988) Degradation of polycyclic aromatic hydrocarbon compounds under various redox conditions in soil-water systems. Appl Environ Microbiol 54: $1182-1187$

O'Nell EJ, Monti CA, Pritchard PH, Bourquin AW, Ahearn DG (1985) Effects of lugworms and seagrass on kepone (chlordecone) distribution in sediment/water laboratory systems. Environ Toxicol Chem 4:453-458

Rav-Acha C, Rebhun M (1992) Binding of organic solutes to dissolved humic substances and its effects on adsorption and transport in the aquatic environment. Wat Res 26: $1645-1654$

Reise K (1983) Experimental removal of lugworms from marine sand affects small zoobenthos. Mar Biol 74:327-332

Retraubun ASW, Dawson M, Evans SM (1996) Spatial and

This article was presented by John Gray (Senior Editonal Advisor), Oslo, Norway temporal factors affecting sediment turnover by the lugworm Arenicola marina (L.). J Exp Mar Biol Ecol 201: $2.3-.35$

Rijken M (1979) Food and food uptake in Arenicola marina. Neth J Sea Res 13:406-421

Shians MP, Jambard-Sweet D (1986) Polycyclic aromatic hydrocarbons in surficial sediments of Boston Harbour, Massachusetts, USA. Mar Poll Bull 17:469-472

Spain JC, Pritchard PH, Bourquin AW (1980) Effects of adaptation on biodegradation rates in sediment/water cores from estuarine and freshwater environments. Appl Environ Microbiol 40:726-734

Swartz RC, Schults DW, DeWitt TH, Ditsworth GR, Lamberson JO (1990) Toxicity of fluoranthene in sediment to marine amphipods: a test of the equilibrium partitioning approach to sediment quality criteria. Environ Toxicol Chem 9:1074-1080

Taghon GL, Prahl FG, Sparrow M, Fuller CM (1994) Lipid class and glycogen content of the lugworm Abarenicola pacifica in relation to age, growth rate and reproductive condition. Mar Biol 120:287-295

Van Duyl FC, Kop AJ, Kok A, Sandee AJJ (1992) The impact of organic matter and macrozoobenthos on bacterial and oxygen variables in marine sediment boxcosms. Neth $\mathrm{J}$ Sea Res 29:343-355

Yingst JY, Rhoads DC (1980) The role of bioturbation in the enhancement of bacterial growth rates in marine sediments. In: Tenore $\mathrm{KR}$, Coull $\mathrm{BC}$ (eds) Marine benthic dynamics. University of South Carolina Press, Columbia, p 407-421

Zebe E, Schiedek D (1996) The lugworm Arenicola marina: a model of physiological adaptation to life in intertidal sediments. Helgol Meeresunters 50:37-68

Manuscript received: October 25, 1996

Revised version accepted: June 17, 1997 